О. Є. Пахомов, О. М. Василюк

Дніпропетровський національний університет ім. Олеся Гончара

\title{
ВПЛИВ АНТРОПОГЕННИХ ФАКТОРІВ НА АКТИВНІСТЬ ТРАНСФЕРАЗ НА ФОНІ СЕРЕДОВИЩЕТВІРНОЇ ФУНКЦЇ̈ ССАВЦІВ
}

Середовищетвірна активність ссавців має велике значення для нейтралізації забруднення на техногенно трансформованих територіях. Екскреторна та рийна активність деяких видів ссавців проявлясться зниженням активності аланінамінотрансферази (АлАт) на 59-62 \% на фоні стабілізації активності аспартатамінотрансферази (АсAT). Показано токсичну дію іонів цинку на водорозчинну фракцію білка в умовах комбінованої дії антропогенних чинників. Комбінований вплив рийної активності ссавців і цинку сприяв підвищенню $\left(t / t_{0,05}=1,15\right.$ та 1,42$)$ активності АлАТ на фоні зниження активності AcAT $\left(t / t_{0,05}=1,22\right.$ та 1,15). В умовах антропогенного навантаження великого значення набувають прості та чутливі методи визначення змін навколишнього середовища з використанням трансаміназ.

\section{А. Е. Пахомов, Е. М. Василюк}

Днепропетровский нацииональный университет им. Олеся Гончара

\section{ВЛИЯНИЕ АНТРОПОГЕННЫХ ФАКТОРОВ \\ НА АКТИВНОСТЬ ТРАНСФЕРАЗ НА ФОНЕ СРЕДООБРАЗУЮЩЕЙ АКТИВНОСТИ МЛЕКОПИТАЮЩИХ}

Средообразующая активность млекопитающих имеет большое значение для нейтрализации загрязнения техногенно трансформированных территорий. Экскреторная и роющая активность млекопитающих проявляется снижением активности аланинаминотрансферазы (АлАТ) на 59-62 \% на фоне стабилизации активности аспартатаминотрансферазы (АсAT). Показан токсический эффект цинка на водорастворимую фракцию белков в условиях комбинированного действия антропогенных факторов. Комбинированное воздействие роющей активности млекопитающих и цинка повышает $\left(t t_{0,05}=1,15\right.$ и $1,42)$ активность АлАТ на фоне снижения активности АсАТ $\left(t / t_{0,05}=1,22\right.$ и 1,15). В условиях антропогенных нагрузок на экосистемы болышое значение имеют простые и чувствительные методы определения изменения факторов окружающей среды с использованием трансаминаз.

$$
\text { O. E. Pakhomov, O. M. Vasyljuk }
$$

Oles’ Honchar Dnipropetrovsk National University

\section{ANTHROPOGENIC INFLUENCE ON THE TRANSAMINATION ENZYMES ACTIVITY UNDER THE ENVIRONMENTAL FORMING MAMMALS ACTIVITY}

Mammals' environmental forming activity has great importance for the neutralisation of transformed technogenic and polluted soils. Mammals' fossorial activity and excretions inhibit alanine aminotransferase (ALT) activity by 59-62 \% under the stabilizing effect of aspartate aminotransferase (AST). The toxic effect of zinc ions on water-soluble protein fraction under the combined effect of anthropogenic factors is shown. The combined effect of mammals fossorial activity and zinc increases the ALT activity $\left(t / t_{0,05}=1.15\right.$ and 1.42 respectively) against decreasing AST activity $\left(t / t_{0,05}=1.22\right.$ and 1.15$)$. The great impor- 
tance is given to simple and sensitive indicators of environmental changes: transaminases and water-soluble enzymes fractions connected with biosynthesis process.

\section{Ветуп}

Цинк - есенціальний мікроелемент, кофактор багатьох ферментів, що беруть участь у метаболізмі нітрогену, фотосинтезі, біосинтезі нуклеїнових кислот, білків тощо. При підвищених концентраціях $Z n$, як і інші метали, токсично впливає на ріст і морфогенез рослин [11]. Велика кількість праць вивчає накопичення $Z n$ у вимикачів i гіперакумуляторів двох контрастних груп рослин, що накопичують метал у підземних або надземних органах [7; 12].

Істотно менше відомо про розподіл $Z n$ на тканинному рівні у кореневій системі [19], що необхідно для розуміння механізмів його токсичної дії, морфофізіологічних механізмів детоксикації. Зростання кореня визначається поділом клітин, їх розтягненням. Коріння рослин забезпечує першу ланку захисту від токсичної дії важких металів (BM) при їх надходженні до рослини (відбувається інгібування ії росту та розвитку). Коріння рослин часто використовують як тест-об'єкт при вивченні токсичної дії різних ВM [7; 22]. У попередніх дослідженнях 3'ясовано розподіл цинку по тканинах паростків кукурудзи. Цинк виявлено в усіх тканинах кореня. У клітинних оболонках його більше [13; 14], ніж у протопластах. В апікальній і середній ділянках (меристема та зона розтягування), а також у зростаючих примордіях бічних коренів цинк виявлявся також у значних кількостях. Найменший вміст металу виявлено в клітинах серцевини. $Z n$ впливав не тільки на розподіл, а і на розтягнення клітин. Результати гістохімічного та кількісного аналізу розподілу та накопичення Zn у коренях і пагонах паростків кукурудзи свідчать про належність кукурудзи до рослин-вимикачів, що накопичують $Z n$ переважно у підземних органах, примордіях бічних коренів, у результаті надходження із провідних тканин, про що свідчить його низький вміст у клітинах, що оточують примордії. Пересування $Z n$ у меристематичні клітини може пояснюватися його участю у ростових процесах, а, з іншого боку, побічно свідчить про можливі відмінності у внеску апопластного та симпластного шляху при його пересуванні по тканинах у різних ділянках кореня [7]. Зв'язування $Z n$ із матеріалом клітинних оболонок може розглядатися як один із можливих механізмів детоксикації [2; 6; 13].

Співвідношення вмісту металу в апопласті та протопласті може бути різним у рослин - вимикачів та гіперакумуляторів, що, у свою чергу, може бути наслідком різної ефективності механізмів транспорту ВМ у вакуолі клітин кореня і їх завантаження в судини ксилеми [7; 19]. Zn обмежено надходить у вакуолі клітин кореня та значно - у судини ксилеми у гіперакумулятора Thlaspi caerulescens L. порівняно з вимикачем T. arvense L., тому що у T. caerulescens L. високий внутрішньоклітинний рівень гістидину [11]. Підвищений вміст металу у вакуолях клітин кореня T. arvense L. (вимикач) порівняно з T. caerulescens L. (гіперакумулятор) спостерігався і тоді, коли його вміст у апопласті обох видів був подібним [15]. Вміст Zn у цитоплазмі гіперакумуляторів дуже низький [14]. Таким чином, токсичний вплив ВМ порушує два основні процеси, що визначають ріст кореня: розподіл і розтягнення клітин [2; 8]. Зниженню токсичного впливу іонів цинку сприяють екологічні чинники, а саме екскреторна та рийна активність ссавців. Екскреторна та рийна активність Mammalia має велике значення для процесів грунтоутворення $[1 ; 9 ; 10 ; 16 ; 18]$, сприяє формуванню видового різноманіття грунтового зооценозу [1]. Безпосередньо впливаючи на розвиток автотрофів, грунториї опосередковано формують грунтотвірні процеси та підвищують видове різноманіття 
рослин [1]. Значний вміст ВМ стимулює вивчення їх впливу та міграції в умовах екскреторної та рийної активності ссавців [1].

Мета цієї роботи - оцінити вплив антропогенного навантаження на функціональну активність трансфераз на фоні середовищетвірної активності ссавців в умовах степового Придніпров'я.

\section{Матеріал і методи досліджень}

У цьому дослідженні визначено вплив екскреторної (на прикладі Sus scrofa L. та Capreolus capreolus L.) та рийної активності (на прикладі малих грунториїв) Mammalia на ріст і розвиток деяких рослин в умовах підвищеного вмісту солей цинку, що має велике значення для відновлення біорізноманіття в умовах антропогенного навантаження [3; 22; 23]. Для визначення ступеня впливу ВМ на навколишне середовище потрібні досить чутливі індикатори - ферменти азотного метаболізму. У зв'язку з цим вивчено вплив екскреторної та рийної активності Mammalia на ріст і розвиток Glechoma hederacea L. (як домінантного виду травостою) за допомогою визначення динаміки активності ферментів азотного метаболізму (нМоль піровіноградної к-ти/мл·с) аспартатамінотрансферази (АсАТ, КФ 2.6.1.1) та аланінамінотрансферази (АлАТ, КФ 2.6.1.2) та вмісту білків водорозчинної фракції (мг/мл) в умовах підвищеного вмісту солей цинку. АсАТ і АлАТ - частина ферментативної системи, за допомогою якої утилізується первинний продукт фотосинтезу в аспартатної групи $\mathrm{C}_{4}$-рослин - аспартат. У роботі достовірною вважали різницю між вибірками при $p<0,05$ [5].

Дослідження здійснювали в умовах Присамарського міжнародного біосферного стаціонару ім. О. Л. Бельгарда (с. Андріївка Новомосковського району Дніпропетровської області). Як контроль обрано територію без впливу ссавців і незабруднену цинком (липо-ясенева діброва із зірочником ланцетолистним (Stellaria holostea L.)). Цинк вносили у грунт у вигляді солі $\mathrm{ZnSO}_{4} \cdot 7 \mathrm{H}_{2} \mathrm{O}-1,15,5,75$ та 11,50 г/ $\mathrm{m}^{2}$, що відповідає 1,5 та 10 ГДК. Через місяць після внесення солі цинку згідно з методикою визначено загальну активність ферментів АлАТ та АсАТ як індикаторів забруднення екосистем [3; 4; 16; 20; 21] та концентрацію водорозчинної фракції білка в листках Glechoma hederacea L., що домінувала у даному травостої. Дослід виконували за такою схемою:

- екскреторна функція: контроль (ділянка без забруднення Zn та активності ссавців) та ділянка з екскреторною активністю Mammalia;

- рийна функція: контроль (ділянка без забруднення Zn та активності Mammalia), порий Mammalia, контроль Zn 1 ГДК, комбінований вплив порию та Zn 1 ГДК, контроль Zn 5 ГДК, комбінований вплив порию та Zn 5 ГДК, контроль Zn 10 ГДК, комбінований вплив порию та Zn 10 ГДК.

\section{Результати та їх обговорення}

Екскреторна функція Sus scrofa L. та Capreolus capreolus L. сприяла зниженню активності АлАТ (на 60 та 62 \%), АсАТ (на 23 та 35 \%) та білка (на 5 та $35 \%$ відповідно). В умовах рийної активності активність АлАТ знизилась на $75 \%$, АсАТ - на $20 \%$, концентрація білка достовірно не відрізнялась $\left(t / t_{0,05}=0,35\right)$ від контролю (без забруднення $Z n$ та активності Mammalia) в усіх варіантах досліду. В умовах впливу екскрецій активність АлАТ зазнала інгібування на $60 \%$, АсАТ - на $20 \%$, концентрація білка знизилась на $10 \%$. Таким чином, чутливішою до зміни екологічних чинників виявилася АлАТ, але активність даного ензиму перекривалась підвищеною роботою АсАТ, що значно заощаджує ресурси організму в умовах стресу. Гальмування процесів метаболізму нітрогену активніше відбувалося в умовах екскреторної активності Capreolus 
capreolus L., ніж під впливом Sus scrofa L. Рийна активність і екскреторна функція ссавців не сприяли відновленню активності трансаміназ, тобто нормалізації процесів метаболізму нітрогену, що пов'язано із незначним терміном екологічного впливу (рис.).

Визначаючи комбінований вплив рийної активності Mammalia та забруднення цинком на загальну активність АлАТ, спостерігали достовірне зниження показника відносно контролю (без забруднення Zn та активності Mammalia) на 50-81 \%, тоді як для АсАТ відбувалось недостовірне підвищення активності на 13-35 \% відносно контролю (табл. 1).

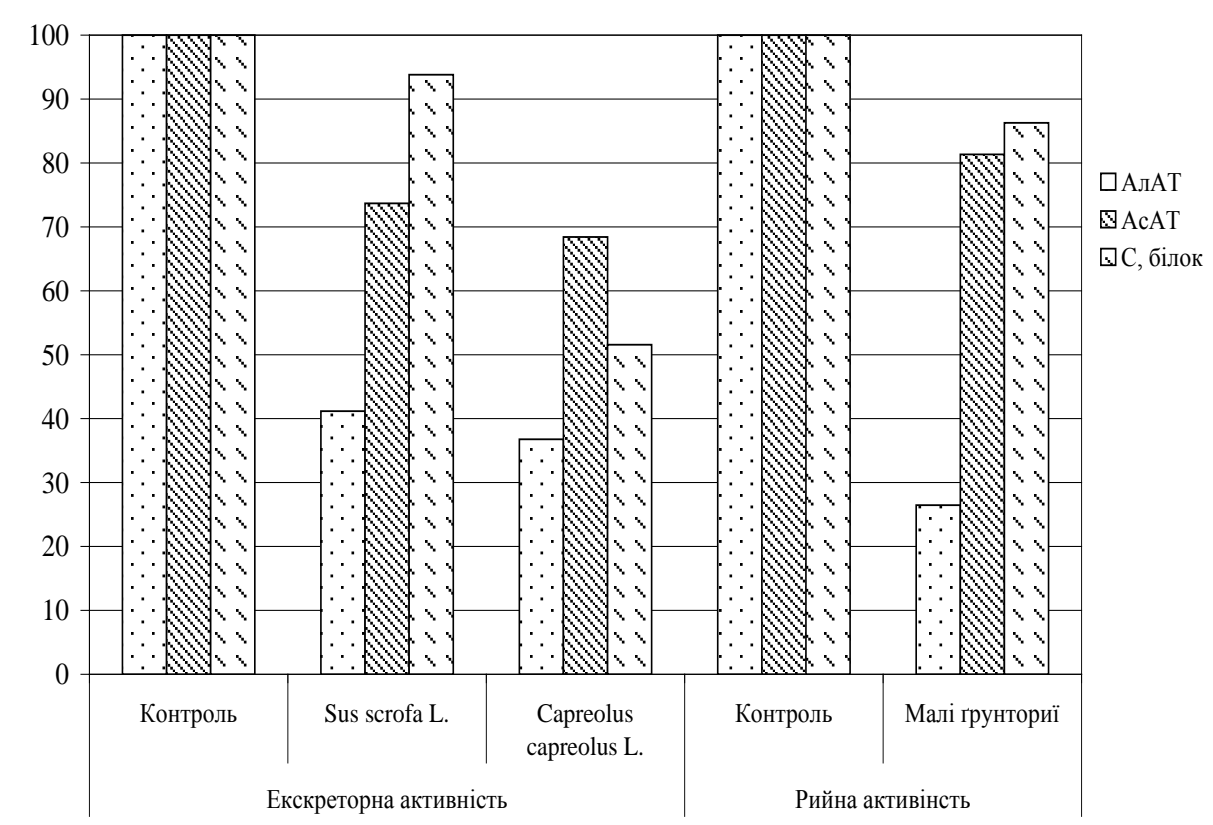

Рис. Вплив екскреторної та рийної активності ссавців на активність ферментів класу трансфераз і концентрацію водорозчинної фракції білків у листках Glechoma hederacea L.

Комбінований вплив рийної активності ссавців на активність трансаміназ

Таблиия 1 у листках Glechoma hederacea L. на фоні забруднення Zn

\begin{tabular}{|c|l|c|c|c|}
\hline Фермент & \multicolumn{1}{|c|}{ Варіант досліду } & $X \pm m$ & Дослід / контроль, $\%$ & $t / t_{0,05}$ \\
\hline \multirow{5}{*}{ АлАТ } & контроль & $1,61 \pm 0,445$ & 100,00 & - \\
\cline { 2 - 5 } & порий & $0,43 \pm 0,177$ & 26,47 & 1,94 \\
\cline { 2 - 5 } & порий, Zn 1 ГДК & $0,76 \pm 0,270$ & 47,06 & 1,06 \\
\cline { 2 - 5 } & порий, Zn 5 ГДК & $1,64 \pm 0,306$ & 101,47 & 0,03 \\
\cline { 2 - 5 } & порий, Zn 10 ГДК & $0,33 \pm 0,102$ & 19,12 & - \\
\hline \multirow{4}{*}{ АсАТ } & контроль & $0,89 \pm 0,177$ & 100,00 & 1,59 \\
\cline { 2 - 5 } & порий & $0,39 \pm 0,088$ & 113,62 & 1,01 \\
\cline { 2 - 5 } & порий, Zn 1 ГДК & $0,57 \pm 0,088$ & 78,12 & 1,96 \\
\cline { 2 - 5 } & порий, Zn 5 ГДК & $0,19 \pm 0,051$ & 135,25 & 1,03 \\
\cline { 2 - 5 } & порий, Zn 10 ГДК & $0,75 \pm 0,150$ & 85,14 & \\
\hline
\end{tabular}

Примітки: $X$ - середня; $m$ - вірогідний інтервал; $t t_{0,05}-$ критерій сугтєвості різниць.

Сукупний ефект рийної активності та солей $Z n$ сприяв збільшенню активності АлАТ на 64-166 \%, АсАТ - на 14 \% 3 мінімальною (1 ГДК) та середньою (5 ГДК) концентраціями металу. Максимальна концентрація $\mathrm{Zn}$ достовірно інгібує процеси метаболізму нітрогену в листках досліджуваної рослини на $30-50 \%(t=1,14)$ відносно кон- 
тролю для відповідної концентрації металу. Спостерігали поперемінну зміну активності ензимів, що забезпечує протекторну та адаптаційну дію біохімічних систем на фоні економії ресурсів рослинного організму в умовах антропогенного пресу (табл. 2).

Комбінований вплив рийної активності ссавців

Таблиия 2

на активність трансаміназ у листках Glechoma hederacea L. на фоні забруднення Zn

\begin{tabular}{|c|c|c|c|c|}
\hline Фермент & Варіант досліду & $X \pm m$ & Дослід / контроль, \% & $t / t_{0,05}$ \\
\hline \multirow{8}{*}{ ААлАТ } & контроль & $1,61 \pm 0,445$ & 100,00 & \multirow[b]{2}{*}{1,94} \\
\hline & порий & $0,43 \pm 0,177$ & 26,47 & \\
\hline & контроль, Zn 1 ГДК & $0,28 \pm 0,177$ & 100,00 & \multirow{2}{*}{1,15} \\
\hline & порий, Zn 1 ГДК & $0,76 \pm 0,270$ & 266,67 & \\
\hline & контроль, Zn 5 ГДК & $1,00 \pm 0,177$ & 100,00 & \multirow{2}{*}{1,42} \\
\hline & порий, Zn 5 ГДК & $1,64 \pm 0,306$ & 164,29 & \\
\hline & контроль, Zn 10 ГДК & $0,66 \pm 0,204$ & 100,00 & \multirow{2}{*}{1,14} \\
\hline & порий, Zn 10 ГДК & $0,33 \pm 0,102$ & 50,00 & \\
\hline \multirow{8}{*}{ AcAT } & контроль & $0,89 \pm 0,177$ & 100,00 & \multirow{2}{*}{1,97} \\
\hline & порий & $0,39 \pm 0,088$ & 44,00 & \\
\hline & контроль, Zn 1 ГДК & $0,50 \pm 0,088$ & 100,00 & \multirow{2}{*}{0,44} \\
\hline & порий, Zn 1 ГДК & $0,57 \pm 0,088$ & 114,29 & \\
\hline & контроль, Zn 5 ГДК & $0,41 \pm 0,135$ & 100,00 & \multirow{2}{*}{1,22} \\
\hline & порий, Zn 5 ГДК & $0,19 \pm 0,051$ & 45,71 & \\
\hline & контроль, Zn 10 ГДК & $0,81 \pm 0,135$ & 100,00 & \multirow{2}{*}{1,15} \\
\hline & порий, Zn 10 ГДК & $0,57 \pm 0,088$ & 70,59 & \\
\hline
\end{tabular}

Примітки: див. табл. 1.

Спостерігали зниження концентрації білків водорозчинної фракції на 10-70 \% у листках Glechoma hederacea L. на фоні екзогенного забруднення Zn в усіх варіантах досліду відносно контролю (без внесення солей металу та рийної активності). Найбільшого зниження зазнав показник за умови дії солі $\mathrm{Zn}$ у максимальній

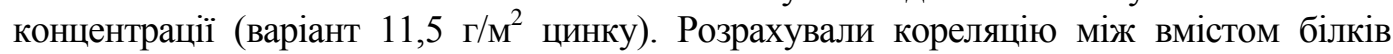
водорозчинної фракції та концентрацією солей $Z n$. Концентрація білка перебувала у негативній кореляції від концентрації $Z n(r=-0,85)$, що доводить токсичну дію даного металу в усіх варіантах досліду (табл. 3).

Таблиця 3

Комбінований вплив рийної активності ссавців на концентрацію білків у листках Glechoma hederacea L. на фоні екзогенного забруднення $\mathrm{Zn}$

\begin{tabular}{|l|c|c|c|}
\hline \multicolumn{1}{|c|}{ Варіант досліду } & $X \pm m$ & Дослід / контроль, $\%$ & $t / t_{0,05}$ \\
\hline Контроль & $1,82 \pm 0,285$ & - & - \\
\hline Порий & $1,68 \pm 0,203$ & 91,9 & 0,33 \\
\hline Порий, Zn 1 ГДК & $1,39 \pm 0,085$ & 76,2 & 1,14 \\
\hline Порий, Zn 5 ГДК & $1,49 \pm 0,124$ & 81,5 & 0,85 \\
\hline Порий, Zn 10 ГДК & $0,55 \pm 0,045$ & 30,2 & 3,45 \\
\hline
\end{tabular}

Примітки: див. табл. 1.

Концентрація водорозчинної фракції білка в листках Glechoma hederacea L. в умовах рийної активності ссавців не спростувала нульової гіпотези $\left(t / t_{0,05}=0,35, p>\right.$ $0,05)$ порівняно з контролем, тоді як у випадку забруднення у спектрі концентрацій 1 , 5, 10 ГДК цей показник суттєво відрізнявся (табл. 3) як від контрольного (без унесення солей металу та рийної активності), так і відносно контролю (табл. 4) з відповідною концентрацією солей металу $\left(t / t_{0,05}=1,72,4,26\right.$ та 2,24, $p<0,05$ та 0,01$)$. 
Комбінований вплив рийної активності ссавців на концентрацію білків у листках Glechoma hederacea L. на фоні забруднення Zn

\begin{tabular}{|c|c|c|c|}
\hline Варіант досліду & $X \pm m$ & Дослід / контроль, \% & $t / t_{0,05}$ \\
\hline Контроль & $1,77 \pm 0,061$ & \multirow{2}{*}{94,7} & \multirow{2}{*}{0,35} \\
\hline Порий & $1,68 \pm 0,203$ & & \\
\hline Контроль, Zn 1 ГДК & $1,25 \pm 0,051$ & \multirow{2}{*}{110,0} & \multirow{2}{*}{1,72} \\
\hline Порий, Zn 1 ГДК & $1,37 \pm 0,027$ & & \\
\hline Контроль, Zn 5 ГДК & $1,29 \pm 0,036$ & \multirow{2}{*}{118,0} & \multirow{2}{*}{4,26} \\
\hline Порий, Zn 5 ГДК & $1,51 \pm 0,021$ & & \\
\hline Контроль, Zn 10 ГДК & $0,76 \pm 0,056$ & \multirow{2}{*}{72,6} & \multirow{2}{*}{2,24} \\
\hline Порий, Zn 10 ГДК & $0,55 \pm 0,046$ & & \\
\hline
\end{tabular}

Примітки: див. табл. 1.

При внесенні солей металу у середній і малій кількості спостерігали підвищення концентрації білка на 10-18 \%, тоді як збільшення концентрації полютанту до 10 ГДК інгібує функціональну активність білкового обміну до 72 \% порівняно з відповідним контролем $(1,5$ та 10 ГДК) та утричі відносно контролю без унесення солей металу та рийної активності тварин (див. табл. 3,4 ).

\section{Висновки}

Екскреторна функція та рийна активність Sus scrofa L. та Capreolus capreolus L. проявляється у зниженні активності АлАт на 59-62\% на фоні стабілької активності AcAT. Зниження рівня метаболізму нітрогену може бути пов'язане зі значним механічним ушкодженням грунтів, у результаті чого спостерігали порушення мікробіологічної та біохімічної активності едафотопу.

Виявлено токсичну дію іонів цинку $(r=-0,85)$ на концентрацію водорозчинної фракції білка в умовах комбінованої дії чинників.

Комбінований вплив рийної активності ссавців та цинку сприяв достовірному $\left(t / t_{0,05}=1,15\right.$ та 1,42) підвищенню активності АлАТ на фоні зниження активності AcAT $\left(t / t_{0,05}=1,22\right.$ та 1,15$)$ відносно контролю $з$ відповідною концентрацією $Z n(1,5$ та 10 ГДК).

Використання ссавців у відновленні біорізноманіття в умовах напруженого техногенного тиску на довкілля - екологічно чистий та безпечний захід, який сприяє поліпшенню природних екологічних систем, дає позитивні результати в умовах степового Придніпров'я.

\section{Бібліографічні посилання}

1. Булахов В. Л. Біологічне різноманіття України. Дніпропетровська область. Ссавці (Mammalia) / В. Л. Булахов, О. Є. Пахомов. - Д. : Вид-во Дніпропетр. ун-ту, 2006. - 355 с.

2. Влияние нитратов свинца, никеля и стронция на деление и растяжение клеток корня кукурузы / А. Д. Кожевникова, И. В. Серегин, Е. И. Быстрова и др. // Физиология растений. - 2009. Т. 56. - С. 268-277.

3. Дзюбак О. І. Вплив хлоридного засолення на морфометричні та біохімічні показники рослин у динаміці росту та розвитку / О. І. Дзюбак, О. М. Василюк // Фундаментальні та прикладні дослідження в біології. Матер. I Міжнар. наук. конф. - Т. 2. - Донецьк : ТОВ «Цифрова типографія», 2009. - С. 231-232.

4. Добрынина В. И. Учебник биологической химии. - М. : Гос. изд-во мед. лит-ры, 1963. - 447 с.

5. Доспехов Б. А. Методика полевого опыта. - М. : Агропромиздат, 1985. - 351 с.

6. Методы биохимического анализа растений / Под ред. В. В. Полевого, Г. Б. Максимова. - Л. : Изд-во Ленингр. ун-та, 1978. - 192 с. 
7. Серегин И. В. Роль тканей корня и побега в транспорте и накоплении кадмия, свинца, никеля и стронция / И. В. Серегин, А. Д. Кожевникова // Физиология растений. - 2008. - Т. 55. - С. 3-26.

8. Серегин И. В. Распределение цинка по тканям корня проростков кукурузы и его действие на рост / И. В. Серегин, А. Д. Кожевникова, В. В. Грачева и др. // Физиология растений. - 2011. T. 58, № 1. - C. 85-95.

9. Bulakhov V. L. Usage of vertebrate animals on technogen ecosystems recultivation and purification / V. L. Bulakhov, A. Y. Pakhomov, A. A. Reva // Secotox 97. Abstracts. Ecotoxicology and Environment safety central eastern European conferens. - Jurmala, Latvia, 1997. - P. 198.

10. Bulakhov V. L. Soil burrowers-phytophagans participation in the soil $-\beta$ radioactivity decrease / V. L. Bulakhov, A. Y. Pakhomov // Toxicology Letters. - 1998. - Suppl. - P. 60-61.

11. Bulakhov V. L.Teriogenic formation of soil microflora in steppe woods of Ukraine / V. L. Bulakhov, A. Y. Pakhomov // I FEMS Congress of European microbiologists. Abstract book. - Lubbjax, Slovenia: Cunkazjev Dom, 2003. - P. 368.

12. Chelation by histidine inhibits the vacuolar sequestration of nickel in roots of the hyperaccumulator, Thlaspi caerulescens // K. H. Richau, A. D. Kozhevnikova, I. V. Seregin et al. // New Phytol. 2009. - Vol. 183. - P. 106-116.

13. Comparison of essential and non-essential element distribution in leaves of the $C d / Z n$ hyperaccumulator Thlaspi praecox as revealed by micro-PIXE // K. Vogel-Mikuš, J. Simčič, P. Pelicon et al. // Plant Cell Environ. - 2008. - Vol. 31. - P. 1484-1496.

14. Distribution of $Z n$ in functionally different leaf epidermal cells of the hyperaccumulator Thlaspi caerulescens / B. Frey, C. Keller, K. Zierold, R. Schulin // Plant Cell Environ. - 2000. - Vol. 23. - P. 675-687.

15. Heavy metal specificity of cellular tolerance in two hyperaccumulating plants, Arabidopsis halleri and Thlaspi caerulescens // L. Marquès, M. Cossegal, S. Bodin et al. // New Phytol. - 2004. Vol. 164. - P. 289-295.

16. Lasat M. M. Altered $Z n$ compartmentation in the root symplasm and stimulated $Z n$ absorption into the leaf as mechanisms involved in Zn hyperaccumulation in Thlaspi caerulescens / M. M. Lasat, A. J. M. Baker, L. V. Kochian // Plant Physiol. - 1998. - Vol. 118. - P. 875-883.

17. Pakhomov A. Y. Migration of some micro- and macroelements in environment under influence of digging activity of mammals / A. Y. Pakhomov, V. L. Bulakhov / Central and Eastern European Regional Meeting. Environmental toxicology: Pathways of anthropogenic pollutants in the environment and their toxic effect. - Porabka-Kozubnik, Poland, 1993. - P. 82.

18. Pakhomov A. Y. Activity of trans-amination enzymes as the indicator of biological revegatation of soils Mammalia in transformed ecosystems / A. Y. Pakhomov, O. M. Vasilyuk // Environmental Security for South-East Europe and Ukraine. The Abstracts NATO Advanced Research Workshop (ARW) / NATO Science Series book. - Dnipropetrovs'k, 2011. - P. 74-75.

19. Rout G. R. Effect of metal toxicity on plant growth and metabolism: I. Zinc / G. R. Rout, P. Das // Agronomie. - 2003. - Vol. 23. - P. 3-11.

20. Tolerance, accumulation and distribution of Zinc and Cadmium in hyperaccumulator Potentilla griffithii / P. J. Hu, R. L. Qiu, P. Senthilkumar et al. // Environ. Exp. Bot. - 2009. - Vol. 66. - P. 317-325.

21. Vasilyuk O. M. Physiological and biochemical parameters of plants as markers of a condition of environment / O. M. Vasilyuk, O. I. Dzyubak // Фундаментальні та прикладні дослідження в біології. Матер. I Міжнар. наук. конф. - Т. 2. - Донецьк, 2009. - С. 348-349.

22. Vasilyuk O. M. The trans-amimation enzyme activity in the leaves of Sambucus nigra under high minaralization of small rivers of Steppe Dnieper / O. M. Vasilyuk, A. F. Kulik // Environmental Security for South-East Europe and Ukraine. The Abstracts NATO Advanced Research Workshop (ARW) / NATO Science Series book. - Dnipropetrovs'k, 2011. - P. 84-85.

23. Wong M. H. A comparison of the toxicity of heavy metals, using root elongation of rye grass, Lolium perrene // M. H. Wong, A. D. A. Bradshaw // New Phytol. - 1982. - Vol. 91. - P. 255-261.

Надійшла до редколегії 27.08.2012 